\title{
The Way of the International Cooperation of Higher Education Under the Strategy of "The Belt and Road"
}

\author{
Ting Jiang*, Lei Shi \\ College of Marxism, Xi'an University of Science and Technology, Xi' an, P. R. China \\ Email address: \\ jiangt0126@126.com (Ting Jiang), 1016986303@qq.com (Lei Shi) \\ ${ }^{*}$ Corresponding author
}

To cite this article:

Ting Jiang, Lei Shi. The Way of the International Cooperation of Higher Education Under the Strategy of "The Belt and Road". Science Journal of Education. Vol. 7, No. 3, 2019, pp. 73-80. doi: 10.11648/j.sjedu.20190703.12

Received: July 18, 2019; Accepted: August 13, 2019; Published: August 26, 2019

\begin{abstract}
Under the background of the slow recovery of the global economy, strengthening regional cooperation is an important driving force to promote the development of the world economy, and has become a trend. In 2013, President Xi put forward the the strategy of "The Belt and Road" (B\&R), which not only sought its own development, but also contributed to the development of other countries in line with the historical trend of Chinese wisdom. Over the past five years, the construction of $\mathrm{B} \& \mathrm{R}$ has gradually changed from planning to practice, from vision to reality, and the progress and achievements have exceeded expectations. On the one hand, $B \& R$ provides a new opportunity for the development of higher education in China. On the other hand, higher education provides a guarantee for the implementation of $B \& R$. B\&R is the latest development concept of China's reform and opening up and foreign policy. Many scholars study the development of higher education from the perspective of B\&R. This topic has become a new hot spot of research. In theory, the strategy of B\&R originates from the excellent traditional Chinese cultural thought, is a further explanation of China's foreign policy and foreign concept, and is also a further practice of the new concept put forward since the 18th National Congress of the Communist Party of China (CPC). By studying the cooperation mode of higher education between China and the countries along B\&R, it is beneficial to increase the international exchange and cooperation in higher education in the future, and to strengthen the cooperation in higher education. To strengthen the cooperation of higher education is beneficial to the great development of the higher education in China, to realize the great rejuvenation of China's dream, to promote the construction of the human destiny community and to create a better future for mankind.
\end{abstract}

Keywords: The Belt and Road, Higher Education, Cooperation

\section{Introduction}

In 2013, the concept of "the Silk Road Economic Belt and the 21st-Century Maritime Silk Road" ("B\&R") was put forward by President Xi Jinping. The Strategy of "B\&R" is the result of China's own cognitive changes, and its purpose is to promote the realization of Chinese Dream. Putting forward the strategy of "B\&R" is not only the need for China to expand and deepen its opening to the outside world, but also for strengthening mutual benefit and cooperation with all countries in Asia, Europe and Africa. China will put the strategy of "B\&R" at the top of its foreign policy in the next 8 to 10 years. "B\&R" is not a solo of China, but a chorus of the countries along the route.

China will grasp the principle when China cooperation with the countries along the route: just be a responder and supporter, not to be a leader or contractors.. On this basis, China will pursue different foreign policies according to different types of countries [1]. The construction of "B\&R" not only promotes the realization of the Chinese dream, but also reflects China's responsibility. The role of the world is also conducive to the realization of the purposes of peace and development for the United Nations. Under the strategy of "B\&R", the exchanges and communication between China and the countries along the line will become more comprehensive (as shown in Figure 1). From politics to economy to culture and education, education in every aspect will reach a new height in history. This strategy has also brought new opportunities and challenges to China's higher education. Therefore, we will study the best ways for higher 
education exchanges and cooperation between China and the countries along the "B\&R", deepen the reform measures of China's higher education, optimize the educational structure and improve the quality of running schools; At the same time, learn how to enhance the Soft Power of Education and Culture in China; finally study how to promote peaceful development and achieve win-win cooperation between countries.

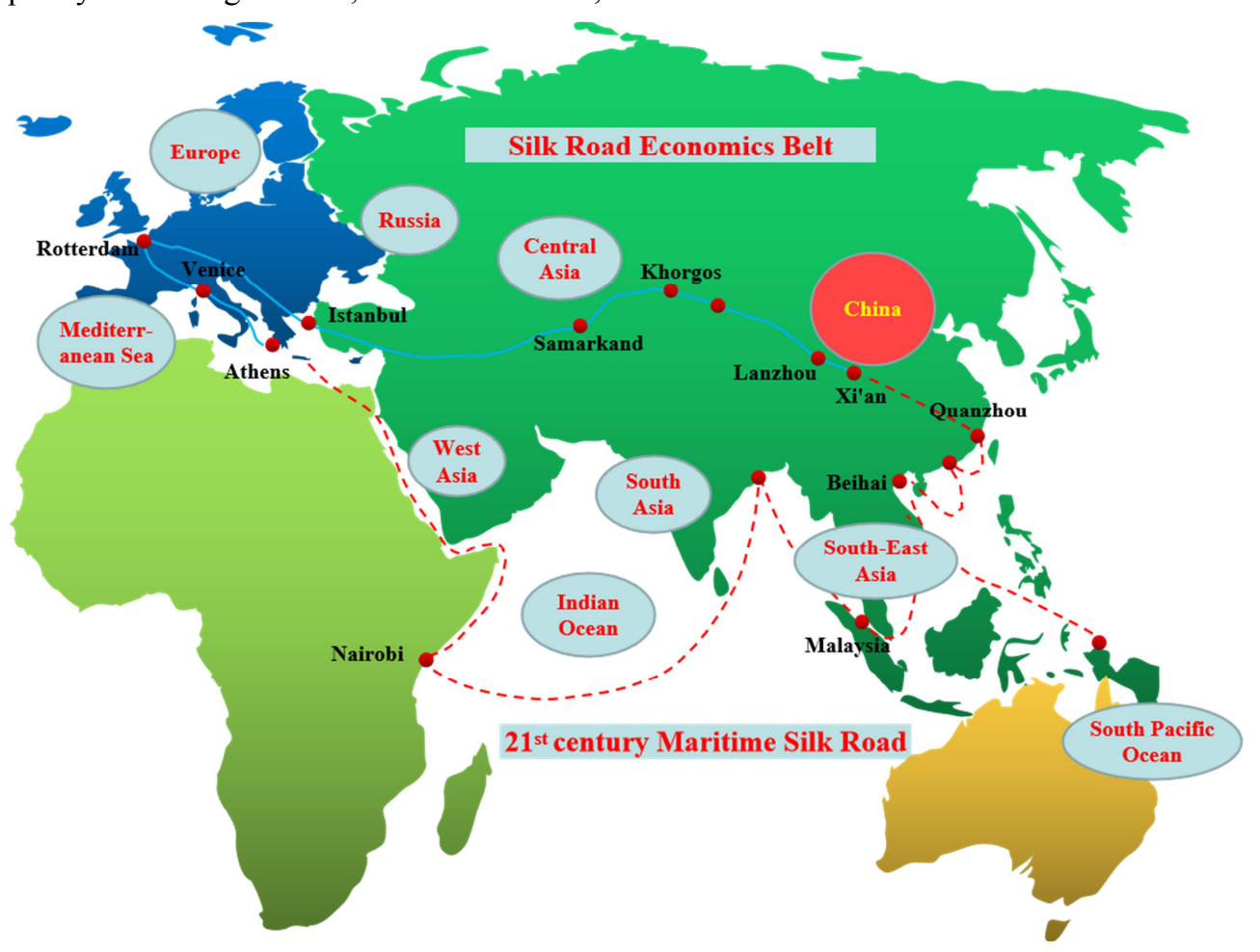

Figure 1. Countries and cities along the " $B \& R$ ".

\section{The Logical Basis of "B\&R"}

The Strategy of "B\&R" is a multilateral cooperation initiative which was put forward by President Xi Jinping in 2013, and aims to create a community of interests and responsibilities with countries along the route which have political mutual trust, economic integration, and cultural inclusion. This strategy is of great significance to the construction of a new open economic system, the all-round opening pattern and the realization of the great rejuvenation of the Chinese nation.

\subsection{The Chinese People's Thought of "View of Justice and Benefit" and "Regarding Harmony as Fundamentality"}

The Chinese nation has always emphasized "Justice", Chinese thought that "the superior man takes justice as the basis" and "Moral superiority over self-interest is an era of stability, and self-interest over morality is an era of chaos". Confucius said, "The gentleman knows what is right; the mean person keeps his mind only on gains." Mencius said, "living is what I want, and justice is what I want; both cannot be obtained, and those who give up life and take justice. The traditional view of justice and benefit also puts forward the dialectical unity thought of the combination of justice and benefit, such as Mozi's, "justice, benefit", and expounds the unity of "justice" and "benefit". It is an excellent tradition left by the Chinese ancestors and followed by the Chinese for thousands of years of moral norms and codes of conduct. This thought has penetrated into the bone marrow of every Chinese [2]. On July 4, 2014, President Xi Jinping pointed out in a speech delivered at Seoul National University in South Korea: "We should pay attention to profit, but also to justice. Only when both justice and benefit are considered, can both justice and benefit be obtained, and only when justice and benefit is balanced, can justice and benefit be mutually beneficial [3]. "The forward and carried out of the strategy of "B\&R" reflects the Chinese people's "view of justice and benefit".

To seek harmony and coexistence is in the genes of the Chinese nation throughout history. It represents the essence of Eastern civilization. Confucius said, "The gentleman aims at harmony, and not at uniformity. The mean man aims at uniformity, and not at harmony. "Mencius said, "Opportunities vouchsafed by heaven are less important than terrestrial advantages, which in turn are less important than the unity among people"; Xunzi said," If you do not lose heaven, you do not lose ground, if you win the peace, you will not waste anything." "He" means "harmony", and also includes the idea of "harmony without uniformity". The report of the 19th National Congress of the CPC pointed out that China adheres to the foreign policy purpose of safeguarding world peace and promoting common development, unswervingly develops friendly cooperation with other countries on the basis of the five principles of peaceful coexistence, and promotes mutual respect, fairness and justice, to form cooperation and achieve 
win-win new international relations [4].

At the 2018 annual meeting of the Boao Forum for Asia, Xi Jinping said: We live at a time with an overwhelming trend toward peace and cooperation. In a world aspiring for peace and development, the cold-war and zero-sum mentality looks even more out of place. Putting oneself on a pedestal or trying to immune oneself from adverse developments will get nowhere. Only peaceful development and cooperation can truly bring win-win or all-win results [5]. China adheres to the road of common development, pursues a win-win strategy of opening up, and actively practices a correct view of justice and benefit. China is willing to share its own development experience and opportunities with other countries. At the same time, China welcomes all countries in the world to ride the "hitchhiking" of China's development [6]. To achieve common development together, China has always adhered to the idea of "regarding harmony as fundamentality", so China emphasizes this idea and puts forward the strategy of "B\&R", so that the people of the world can see that China will not bring war in the process during its rise. On the contrary, China will lead the neighboring countries and even the people of the world to the road of win-win development together.

\subsection{The Concepts of "a Community of Shared Future for Mankind", "Shared Development" and "Win-win Cooperation"}

"A community of shared future for mankind" refers to the existence, communion and destiny of all the countries, regions and peoples in the world, including China [7]. By pondering over the background of the times and the future and destiny of mankind, President Xi Jinping has clearly explained the idea of "a community of shared future for mankind" to the international community on many important occasions. For this important basis, we should actively advocate common development and revitalization among all countries. Mankind has only one earth, and it is home to all countries. Common development, which is the important foundation of sustainable development, serves the long-term and fundamental interests of all the people in the world. As members of the same global village, we should foster a sense of community of common destiny, follow the trend of the times, keep to the right direction, stick together in time of difficulty and ensure that development in Asia and the rest of the world reaches new highs [8]. The idea of "a community of shared future for mankind" not only puts forward universal, feasible and forward-looking plans for the development of the international community, but also conveys the sound of China's peaceful development to the world.

China not only pursues its own development, China also hope that human society can develop together. The strategy of "B\&R" is put forward and formed under these demands, which is the China's proposal for solving the world's problems. This strategy has not only been warmly discussed by the international community, but also strongly supported by the countries along the route. On account of the "a community of shared future for mankind" advocates that all countries in the world are open to each other, harmony without uniformity, harmonious symbiosis, common development, cooperation and win-win, which provides a new strategy for global governance [9].

There is a feature film named "Never forget why you started and keep going" points out that: A rejuvenation of the nation needs broadest circle of friends. Over the past five years, a new type of international relations with win-win cooperation as the core has been widely recognized. In the past five years, "B\&R" has achieved fruitful results by adhering to the principle of co-negotiation, co-construction and sharing. Over the past five years, profound changes have taken place in the global governance system dedicated to promoting human peace and development. Over the past five years, the Chinese people and the people of all countries have joined hands to build a community of shared future for mankind. The concept of shared development is the basic premise of China's handling of international relations. In order to share development, the Chinese government put forward the strategy of "B\&R" in a due course [1].

\subsection{China Firmly Pursues an Independent Foreign Policy of Peace}

China has always adhered to the path of peace and pursued an independent foreign policy of peace. The purpose of its foreign policy is to safeguard world peace and promote common development. China's development will definitely not be at the expense of the interests of other countries. China's national defense policy is a defensive policy, and this policy will definitely not be shaken.

In the report of the 19th National Congress of the CPC, it was clearly stated that: China will never pursue development at the expense of others' interests, but nor will China ever give up its legitimate rights and interests [4]. No one should expect us to swallow anything that undermines our interests. China pursues a national defense policy that is in nature defensive. China's development does not pose a threat to any other country. No matter what stage of development it reaches, China will never seek hegemony or engage in expansion. Under the strategy of "B\&R", the Chinese government will grasp one principle: only to be a responder and supporter, not to be a leader or contractors. On this basis, according to different categories of countries, pursue different diplomatic strategies.

\section{The Opportunities and Challenges of Higher Education in China Under the Strategy of "B\&R"}

\subsection{Three Major Opportunities}

\subsubsection{The Opportunity of Training Talent}

In 2010-2020, Asian countries need to spend \$7.97 trillion on infrastructure construction and maintenance, involving 989 transport and 88 cross-border energy projects [10] Relevant information points out: We should also increase personnel exchange and cooperation between countries along "B\&R", 
strengthening scientific and technological cooperation, co-building laboratories (research centre), international technology transfer centre, maritime cooperation centre, and promoting exchanges of scientific and technological personnel, work together to tackle major scientific, technological problems and jointly enhance our scientific and technological innovation capabilities.

When education is developing, it will lead to the development of industry, so higher education is closely related to the development of economy in the trend of internationalization. Constantly deepening international exchanges and cooperation will inevitably stimulate the country's demand for talent and technology. Central, South and West Asia are rich in resources, but some countries have less talent and less technology, such as transportation, agriculture, minerals and electricity. Therefore, Chinese colleges and universities have important tasks, one is to provide high-quality personnel in communication and cooperation, and another is to provide a high level of practical research results.

\subsubsection{The Opportunity of Running Schools Together}

The key direction of China's higher education cooperation is Central Asia, South Asia and West Asia, which are priority areas to promote the strategy of "B\&R". In some countries of these regions, higher education is relatively weak and the resources of higher education are relatively scarce. China carries out the strategy of running a school out of the higher education in the world, while running the higher education in our own country; we should cooperate with other countries in running schools together. Relevant information points out: We should send more students to each other's countries, and promote cooperation in jointly running schools. China provides 10,000 government scholarships to the countries along "B\&R" every year.

Under the opportunity of "B\&R", the Chinese government attaches great importance to running schools together, constantly expanding the scale of overseas students, encouraging Chinese students to study in countries along "B\&R", and welcoming students from countries along "B\&R" to study in China. On the one hand, after many years of development, China's higher education has a certain strength and rich experience. On the other hand, colleges and universities in China can set up vocational skills training centers to train relevant technical and industrial talents.

\subsubsection{The Opportunity of Cultural Exchange}

Promoting the exchange of education and culture and realizing the mutual understanding among the people is an important part of the "five links" (which President Xi Jinping put forward during his visit to Central Asia, that is, policy communication, road connectivity, smooth trade, currency circulation, and people's common feelings). It is also the key to consolidate the public opinion base of the countries along "B\&R". Central Asia, South Asia, West Asia and other countries and China have a wide range of educational and cultural exchanges. Student communication is an important field of educational communication.
President $\mathrm{Xi}$ Jinping announced in a speech at the Asian-African Summit on April 2, 2015. In the next five years, China will offer 100,000 training opportunities for candidates from developing countries in Asia and Africa and host the annual Asia-Africa Youth Festival, inviting a total of 2,000 Asian and African youth to China [11]. At the same time, China plans to send a certain number of overseas students along the "B\&R". Colleges and universities should seize this opportunity and make good use of government scholarships to recruit students from countries along "B\&R". At the same time, in the framework of counterpart communication, arrange students to the other side of the school for a short-term learning experience and internship, to expand the international perspective. The strategy of "B\&R" has increased the opportunities for cultural exchanges and communication with the international community along "B\&R".

\subsection{Two Major Challenges}

\subsubsection{The Demand of Compound Talents}

In order to realize the cultural blending, public diplomacy and media cooperation between the countries along "B\&R", it is necessary to have complex talents, to be familiar with the policies and conditions of various countries, to be proficient in many languages, to understand local cultures, and to have professional knowledge.

First of all, language is the basis for all communication. It is the link to enhance national interaction, cultural exchange, policy exchange and solidarity. "B\&R" covers 65 countries (as shown in Figure 2), nearly 50 official languages, and nearly 200 ethnic or tribal languages. However, at present, there are only 20 language courses offered in colleges and universities in China. The shortage of language translation talents can not meet the strategic needs of "B\&R". Therefore, higher education needs to strengthen the training of non-universal language talents.

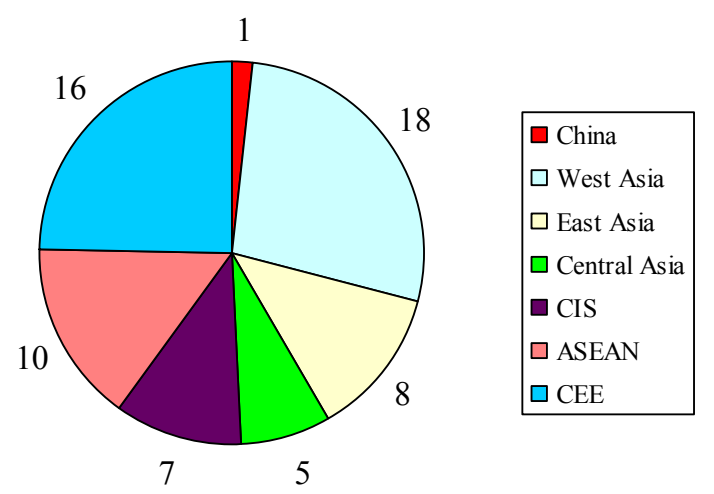

Figure 2. The number of the countries along the " $B \& R$ ".

Secondly, most of the countries along "B\&R" are multi-cultural gathering areas, and cultural problems will arise in the process of carrying out people-to-people exchanges. This requires us to train a group of talents with multicultural cognition, and through these talents to carry out overseas cooperation, exchange, and other activities.

Finally, the talents who are familiar with national policies, 
national conditions and historical changes are needed. Under the strategy of "B\&R", fully understand the culture, policy and national conditions of other countries, can avoid the clash of civilization, strategy and politics with other countries. Therefore, we should strengthen the training of complex talents, and at the same time give full play to the important role of cross-border ethnic groups and overseas Chinese, with the help of these people's understanding of local customs, policies and social conditions can promote the further implementation of the strategy of "B\&R".

\subsubsection{The Demand of Educational Resources and Structures}

The modern Silk Road adheres to the road of opening up. Under the background of "B\&R", China's higher education should rely on its own strength to seek development, and the upgrading of strength needs to be supported by deep financial resources. China's economy continues to develop, becoming the second largest economy in the world. However, in some place, China's school conditions lagged behind the economically developed areas along the "B\&R". How to make rational use of limited basic resources and improve the benefit of educational funds is a realistic problem which must be solved by Chinese higher education in response to the strategic challenge of "B\&R".

Statistics from the Ministry of Education show that in the past five years, the number of overseas students studying in China has increased from 328330 to 442,773 , a growth rate of 34.86. The number of students from countries along the route of "B\&R" has increased from 142,027 to 223,998 . The growth rate is 57.72 , which is higher than the annual growth rate of Chinese students from all over the country [12]. In 2016, China's Ministry of Education put forward the following in "promoting the Joint Construction of ' $B \& R$ ' Educational Action: "In the next three years, China will send 2500 foreign students annually to the countries along "B\&R". In the next five years, 10 overseas science and education bases will be built and 10,000 new students from countries along "B\&R" and will be funded to study in China each year. In the face of a large number of foreign students coming to China, more professional teachers and teaching resources are needed, and the teaching structure needs to be adjusted in time.

\section{An Analysis of the Cooperative Path of Higher Education Between China and the Countries Along "B\&R"}

"Troubled, improve yourself, valued, improve the world", China has been responsible for "take the world as one's own duty" since ancient times. Today, China is about to build a well-off society in an all-round way, as China steps into the ranks of the moderately developed countries, the launch of the strategy of "B\&R" and the formation of the Asian Infrastructure Investment Bank both reflect this sentiment [13]. In 2018, China took a more active attitude to promote the internationalization of China's higher education, so that the countries along "B\&R" and the world could understand China and create a better future for mankind. The enlightenment of the cooperation between China and the countries along "B\&R" in higher education are as follows.

\subsection{To Train Compound Talents}

In order to meet the needs of "B\&R" for "high precision" and compound talents, it is of great significance to select and evaluate talents from many ways. In February 2014, the Ministry of Education issued the "Promotion Plan for the Construction of a New Type of University think Tank with Chinese characteristics", which provided a new guide for the construction of talents and laid a policy foundation for the cultivation and selection of "B\&R" talents. In order to meet the demand of "B\&R" for "high precision" and compound talents, according to the relevant laws and regulations of the state, the construction of university think tanks can be carried out in order to rely on the resources and influence of colleges and universities. In order to provide various conditions of social practice and scientific research for outstanding talents, aiming at the specific problems of the theory and practice of "B\&R", the university think tank is used to coordinate and communicate in many aspects.

At present, such institutions as the Strategic Research Institute of Tsinghua University, the International Institute of Strategic Studies of Peking University, the Fudan Development Research Institute established by Fudan University, the Slavic Research Center established by Capital normal University, the Silk Road Research Institute set up by Northwestern University. Renmin University of China established the Silk Road College, mainly enrolling students from the countries along "B\&R", majoring in law, mainly studying Chinese culture and politics, has played a positive role in promoting the cultivation of talented persons of "B\&R". Higher education institutions should make a thorough study of "B\&R", plan to put forward the specific standards of "high precision" and compound talent training, and strengthen the training of compound talents. So that it not only has relatively solid professional knowledge, but also has an international perspective, organizational implementation and theoretical summary of the ability to cope with the implementation of "B\&R" in the process of various problems and challenges.

\subsection{To Train High Quality Faculty}

Teachers are the most important components in the process of talent training, and the construction of teachers' team plays a vital role in the cultivation of talents in colleges and universities. Chinese universities and relevant educational departments should also extensively carry out academic exchanges at home and abroad, promote in-depth exchanges between domestic universities and first-class universities abroad, and provide more and more valuable resources for their running schools [14]. Teachers are the most important resources of colleges and universities, each university in China should make detailed training and development plan for teachers. To create favorable conditions, so that teachers can 
devote themselves to teaching tasks without any worries, create opportunities to encourage teachers in schools to exchange abroad and learn advanced educational concepts and teaching methods abroad. Improve the international level of teachers as a whole.

The introduction of high-quality teachers in the international community can make up for the deficiencies in teaching in domestic colleges and universities. The state and schools should cooperate with each other and provide generous treatment. Preferential policies and favorable working conditions can mobilize domestic colleges and universities to introduce international outstanding teaching personnel enthusiasm. Therefore, internally, we must ensure the professionalization, scientization and internationalization of teachers' construction in the aspects of teachers' moral construction, professional level, teachers' treatment and teachers' management. Externally, it is necessary for us to introduce high-quality foreign teacher resources, such as attracting more world-class experts and scholars to China for teaching, scientific research and management, and we have plans to introduce high-end talents and academic teams from abroad. Attract overseas talents to return to China, increase the proportion of foreign teachers employed in colleges and universities [15].

\subsection{To Build a Coalition of Universities}

The proposal of "B\&R" should not be closed, but a process of external expansion and internal strengthening. United Nations Educational, Scientific and Cultural Organization (UNESCO) puts forward in "Learn to Survive": "All countries with different levels of development participate in education and work together to complete educational collaboration, which is beneficial to all participating countries." Under the guidance of "B\&R", we should also learn to share in order to promote talent training. On the one hand, we can join hands with "B\&R" along the region to establish a university alliance. On October 17, 2015, 46 Chinese and foreign universities, including Fudan University, Beijing normal University, Lanzhou University, Russian Ural State University of Economics, and Pukyong National University, Strategic Alliance of "B\&R" of Colleges and Universities in Dunhuang, Gansu Province. In order to explore the cultivation of high-quality personnel with international vision and transnational training and cross-border migration of talent training mechanism, at present, there are already "Silk Road University Alliance", "New Silk Road University Alliance" and other alliances in China. On this basis, we can construct a pluralistic university alliance based on the needs of field, specialty and regional development. To serve the training of talent, talent exchange, cultural communication and scientific research cooperation, and provide a platform for cooperation and exchange between universities or regions.

As a community of education, "B\&R" has a holistic role to play. For example, in the areas of high-level consultation, project implementation, and the training and management of foreign students, the university alliance will build a lot of platforms. Open up more channels, constantly attract new members, and strive to create a comprehensive, cross-domain, muti-subject and open high-end alliance.

In order to build a high level alliance of deep exchange among members of "B\&R", to realize mutual knowledge, mutual trust, mutual help, mutual assistance, mutual learning and mutual learning among members of the alliance, it is necessary to establish a joint training system in the mechanism of personnel training. Make efforts on the platform of discipline construction, but also deepen academic dialogue and exchange as well as the strength of cultural promotion.

\subsection{To Build Think Tanks in Colleges and Universities}

"The great age calls for the great strategy, and the great strategy calls for the first-class think-tank." Think tanks play an increasingly critical role in China's economic and social development and political life. The think-tank has the professional research ability and the social public influence, exerts the specialized research ability, designs, formulates the plan and the related policy for the strategy of "B\&R". In addition, think tanks serve as a bridge between government and the public and between policy research and dissemination, helping the international community to gain an in-depth understanding of the strategy of "B\&R", as well as an understanding of the concepts and policies associated with "B\&R", So as to promote the policy communication, strategic docking and the common people. There are many kinds of think tanks, among which university think tanks are the most important one.

First of all, as the birthplace of knowledge, the members of the university think tank are mainly teachers and a small number of professional and technical personnel outside the school. Secondly, colleges and universities have the value of serving the society. On the one hand, it embodies the demand of colleges and universities to seek social value. On the other hand, it promotes the effective utilization of intelligence in colleges and universities. Thirdly, Compared with the official think-tank, the university think tank has a strong academic atmosphere, complete discipline distribution, independent research direction and more just research position. The research on the road of colleges and universities is mainly aimed at "B\&R". The theoretical results put forward are more academic and provide some technical support and theoretical reference for government decision-making. There is no doubt that the objectivity and freedom of university research is more conducive to the scientific decision of the government. Fourthly, compared with the private think-tank, the university think tank has a more stable source of funds, not only the school appropriate funds, funds and government appropriate funds will also have a variety of social donations. In short, there is a stable funding for research. Finally, in the struggle for the related projects of "B\&R", the brand advantages of colleges and universities are more obvious. There are a lot of the advantages of the university think tank, so we should actively build the university think tank. 


\subsection{To Increase Cultural Exchange and Communication}

Education is closely related to culture. One of the important functions of education is to promote cultural inheritance and innovation. China has five thousand years of history and culture. It has carried out all-round educational and cultural exchanges with countries and regions along the route of "B\&R", so that the world can understand China's education and culture, and China's education and culture can go to the world. To promote the great development and prosperity of Chinese education and culture, first, we should build a platform for cooperation and exchange, to promote higher education in China. To pave the way for the countries regions along "B\&R", second, we should promote personnel exchanges between China and the countries and regions along "B\&R", carry out regular exchanges of scholars, and send teachers to countries along the road to carry out research and teaching. Third, we should conduct regular exchanges with countries along "B\&R" during the year of cultural activities, months of activities, and weeks of activities, such as seminars. In order to enhance mutual understanding and realize the exchange of ideas, cultural exchange and experience sharing. Last, we should make good use of Confucius Institute and other overseas talent training platform. Through a series of exchanges and cooperation, spread the Chinese voice, display the image of China, and promote China's development.

The acquaintance of a country lies in the match-making of the people, and the success of the match-making is promoted by the people. Through the international academic forum, academic exchange and other activities, to jointly face and solve the problem of the resources, environment, ecology and other issues which faced by human. The exchange process can promote mutual understanding, mutual trust and cooperation among citizens of countries along "B\&R", promote higher education diplomacy, forum diplomacy, and promote university cooperation. With the help of various academic exchanges and cooperation, we need to deepen the cultural exchanges between countries, to buffer the cultural conflicts, to enhance the cultural understanding between countries, thus providing a more effective way for the cooperation of higher education.

\section{Conclusion}

The construction of "B\&R" is not only contributes to the realization of Chinese Dream, but also to the realization of the purpose of peace and development of the United Nations. Under the strategy of "B\&R", the exchange and communication between China and the countries along the route will become more comprehensive. From politics, economy to culture and education, every aspect of education will reach a new level of history.

From the published papers, it can be found that the higher education research on the subject of "B\&R" mainly studies and analyzes the view of higher education talent, the development of regional higher education, the integration of educational resources and the foreign exchange of domestic colleges and universities. Through the analysis, it is found that the depth and breadth of the research on higher education under the strategy of "B\&R" is not enough, the connection of the research is insufficient. What's more, the combination of micro research and macro research is not enough, so it is necessary to further excavate the theoretical connotation and practical path.

This paper holds that this strategy brings new opportunities and challenges to higher education in our country. The opportunities are the cultivation of talents, the common school-running and the cultural exchange. There are also challenges, including the need for composite talents and the needs of educational resources and structures; In this paper, there are five aspects should be paid attention to in the cooperative path, including the cultivation of the compound talents, the cultivation of high-quality teachers, the establishment of the colleges and universities, the construction of a think tank of colleges and universities, and the increase of cultural exchanges and communication.

In a word, China and the countries along the "B\&R" need to study the measures to deepen the reform of higher education and optimize the educational structure and methods to improve the quality of running schools. The ultimate goal of "B\&R" is to study how to strengthen the soft power of foreign education and culture, how to promote the peaceful development of our country, and how to realize the cooperation and win-win between countries.

\section{Acknowledgements}

We thank the academic editors and anonymous reviewers for their kind suggestions and valuable comments.

This research was supported by the Soft Science Project of Shaanxi Provincial Science and Technology Department (No.2007KR82), Key Research Project of Teaching Reform in Shaanxi Colleges and Universities (No.17BG016), and Scientific Research Project of Higher Education of Shaanxi Institute of Higher Education (No.XGH19033, XGH17009).

\section{References}

[1] Xue Li: The arrival of "The Belt and Road" and "Asia-Europe World" (China Social Sciences Press, China), pp. 99, 2016.

[2] $\mathrm{Wu}$ maochang: Talking about Faithfulness, Attaching Importance to Emotion, Promoting Justice and Building Morality_ _ Study Xi Jinping's exposition on Upholding the Correct View of Justice and benefit,) No. 1, pp. 33-38, 2018.

[3] $\mathrm{Xi}$ jinping: Create the Future of China-South Korea Cooperation and revitalize the Prosperity of Asia, People's Daily, July 5, 2017.

[4] Secure a Decisive Victory in Building a Moderately Prosperous Society in All Respects and Strive for the Great Success of Socialism with Chinese Characteristics for a New Era Delivered at the 19th National Congress of the Communist Party of China. pp. 58-59, October 18, 2017. 
[5] Xi jinping: Openness for Greater Prosperity, Innovation for a Better Future, China Economic Weekly, pp. 20-23, 2018.

[6] Xi jinping: Sailing in the same boat to create a better future for Sino-Latin American relations, People's Daily, November 23, 2016.

[7] Zhou yinzhen: A Study on the Reshaping of China's International Discourse Right under the Guidance of the Theory of "a community of shared future for mankind", Journal of Yunnan Minzu University (Social Sciences), Vol. 35, No. 2, pp. 22-30, 2018.

[8] Xi jinping: Working Together Toward a Better Future for Asia and the World, People's Daily, April 8, 2013.

[9] Building a community of shared future for mankind, Guangming Daily, November 9, 2017.

[10] Mo leiyu, Hong chenwen: During the implementation of the "The Belt and Road" higher Education in China needs timely adjustment, Guangming Daily, May 12, 2015.
[11] Xi jinping: Address at the Asian-African leaders' Conference, People's Daily, April 23, 2015.

[12] Chen rongmin: Study on the Management Strategy of students coming to China from countries along "The Belt and Road", China Higher Education, No. Z3, pp. 69-71, 2017.

[13] Qu zhenyuan: The Construction of "The Belt and Road" and the New Mission of National Education, Guangming Daily, August 13, 2015.

[14] Cheng xueyan: The Way to the Innovative Personnel Training of Higher Education in the Context of the "One Belt and One Road" Internationalization, Theory and Practice of Education, Vol. 36, No. 27, pp. 9-11, 2016.

[15] Jia yu: Pooling the strength of Chinese and Foreign think tanks to promote the Construction of "The Belt and Road", Guangming Daily, May 19, 2017. 